\title{
Water Chemistry Management toward Corrosion for Secondary Cooling Piping of Multi Purpose Reactor GA Siwabessy Indonesia
}

\author{
Geni Rina Sunaryo ${ }^{1}$, Herry Sander ${ }^{2}$, Djarot S. Wisnubroto ${ }^{3}$ \\ ${ }^{1,2}$ BATAN, PTKRN, Bldg. 80, Puspiptek Area, Serpong, Tangerang, 15310, Indonesia \\ ${ }^{3}$ BATAN, Headquarter Office, Kuningan Barat, Jakarta, Indonesia
}

\begin{abstract}
The experimental of inhibitor, oxy and non oxy biocide effectiveness on suppressing the carbon steel by using the secondary water cooling system of RSG GAS was done. The observed parameter are corrosion rate, dissolved oxygen concentration, $p H$ and conductivity. The variation concentration of inhibitor, oxy and non oxy biocide was applied. The corrosion rate and dissolved oxygen are measured by using Gamry electrochemical instrument, $p H$-meter and oxygenmeter, respectively. Whole experiment was carried out at room temperature. Speciment test is carbon steel with diameter of $16 \mathrm{~mm}$ and thickness of $8 \mathrm{~mm}$, with the exposed are of $1 \mathrm{~cm}^{2}$, polished by grid 220 up to 2000. The variation concentration was applied for all chemicals up to $60 \mathrm{ppm}$. From the experiment it is known that the rate corrosion is suppressed by the addition of inhibitor, higher concentration inhibitor will suppress much more. This phenomenon is strongly understandable by the experimental data that shows dissolved oxygen decreasement due to the presence of inhibitor. The higher concentration of inhibitor cause the lower dissolved oxygen concentration. No $\mathrm{pH}$ change observed which is means that the inhibitor does not give any contribution on releasing $\mathrm{H}^{+}$or $\mathrm{OH}^{-}$that causing $\mathrm{pH}$ changing. The addition of oxy biocide suppress corrosion rate from $0.7 \pm 0.02$ mils/yr to $0.5 \pm 0.02$ mils/yr. However, non oxy biocide addition does not give any significant effect.
\end{abstract}

Keywords - rate corrosion, inhibitor, oxy biocide, non oxy biocide.

\section{INTRODUCTION}

Indonesia has three research reactor located in Bandung, Yogyakarta and Serpong. The biggest one with $30 \mathrm{MW}$ is namely GA SIWABESSY. This is a multipurpose reactor, main domains for fundamental and applied science, industry, human health care and environmental studies, as well as nuclear energy applications and the development of nuclear science and technology related human resources. This research reactor has two cooling systems, primary and secondary. Primary cooling system is a close system and secondary is an open air system but semi close. In the purpose to maintaining the primary structure integrity as long as the designed life and suppressing the unexpected radioactive material produced by neutron irradiation coming from the core, the mineralized water is used for primary cooling water. Differ with this, the secondary system apply raw water which is coming from the PUSPIPTEK tap water. The pre treatment is applied for reducing the insoluble particles by depositing method in the water basin for few days. The following treatment is based on how to prevent either delay the metallic induced corrosion, scaling and microbe induced corrosion problem, therefore inhibitor and biocides chemicals are added up into the secondary water periodically with a certained concentration that is suggested by the company and as mentioned in Safety Analyses Report (SAR). In fact, how far the effectiveness of recommended concentration by company is not yet known. The prices of those chemicals are not cheap one. Therefore, it becomes a significant parameter that contributes a lot toward the annual maintenance budget. Less concentration will suppress the maintenance operating budget.

A continue operation of RSG GAS has to be carefully assessed, especially from the material structure point of view[1-3], in 30 years operation. The basic consideration for designing this facility for long life operation is based on material selection and strategy to managing the whole facility including the operating environment. Stainless Steel and aluminum are the main material used in the primary system, and carbon steel is the most material used for secondary system. One mechanism that hold as a key role for these materials in RSG GAS is corrosion problems. Lots of corrosion study towards those materials have to be understood well and are published elsewhere.[4-13] Specific publications about carbon steel corrosion also have been reported elsewhere.[14-17] However, different environment identic with different contaminant and may cause different accelerated corrosion. Therefore, understanding well about corrosion problem towards carbon steel under RSG GAS secondary environment has to be carried out in the purpose of gaining long life operation more than 30 years. the experiment related with the secondary water cooling of RSG GAS should be carried out. 
One of the experiment for understanding those secondary water management effectiveness was done by implementing cupon corrosion surveillance and have been reported on the previous conference.[2,3] The visual result shows significant accelerated corrosion on the carbon steel cupons. The passive layer formation on the carbon steel to prevent further oxidation is known and highly exploited in industrial applications. Beside, inhibitor, the biocide chemicals also being added to control microorganism as a living substance that make inevitable environment. It induces biofilms formation as well and corrode the surfaces and give an extreme significant deteorization.[14] The effectiveness of those is considered to be the important parameter that should be understood well. The effect of the present biocides towards suppressing the microbial growth was done and reported elsewhere.[1]

Corrosion process is a redox reaction, which is both reactions (reduction and oxidation reactions) have a similar rate. Passivating the cathode by formatting hardly dissolved metal hydroxide $(\mathrm{MOH})$ will suppress the further corrosion process. Finally, the anode's rate reaction might be suppressed as well, then slowering the whole corrosion process. Therefore, the corrosion rate of carbon steel is the important parameter that should be determined under the inhibitor added and biocide as well. Dissolved oxygen is playing as a key parameter on the rate of oxidation process. Hence, the effect of inhibitor and biocide addition toward the concentration of oxygen has to be determined as well. .

The objective of the present experiment is to determine the corrosion rate of carbon steel under the inhibitor and biocide used at RGS GAS. These data will be added up as RSG GAS secondary cooling water data base, as a reference for the further safety analyses report evaluation.

Methodologies applied for determining corrosion rate is based on electrochemical, and the determining the concentration of dissolved oxygen is measured by using oxygenmeter detector. The concentration of inhibitor and biocide in this experiment is varied adjusted by the concentration range applied at RSG GAS.

\section{METHODOLOGY}

\subsection{Equipment}

Experiments were conducted at room temperature and atmospheric pressure in a electrochemical glass (Fig. 1). A threeelectrode setup and one hole for sample were used. A small magnetic stirrer with a speed control unit ( $0 \mathrm{rpm}$ to 5,000 rpm) was used. A varied concentration of inhibitor, up to $150 \mathrm{ppm}$, in tap water as a solvent was used for the solutions.

The $\mathrm{pH}$ was monitored with an electrode immersed in the electrolyte. The expected $\mathrm{pH}$ is neutral. Oxygen concentration was monitored using an Oxygen meter. Electrochemical measurements were made using a Gamry Instruments.

\subsection{Sample}

Carbon steel materials from pipes are tested by using X-Met. Chemical compositions are given in Table 1. The material was machined from the parent material into a coin shape of $8 \mathrm{~mm}$ in thickness and $16 \mathrm{~mm}$ in diameter. Then, polished by using sandpaper of grid 220, 400, 800, 1000 up to 2000. The exposed area of the specimen was $1 \mathrm{~cm}^{2}$.

\subsection{Procedure}

The glass cells were filled with $500 \mathrm{ml}$ of inhibitor solutions with a certained concentration. Monitoring of $\mathrm{pH}$ was done on line. The $\mathrm{O}_{2}$ concentration was measured to judge when the solution was in equilibrium. The temperature was maintained constant at room temperature in all experiments. Before each experiment, the sample surface was polished using 500-grit silicon carbide $(\mathrm{SiC})$ paper, washed with alcohol, rinsed with distilled water and then mounted on the specimen holders, and immersed into the inhibitor solutions.

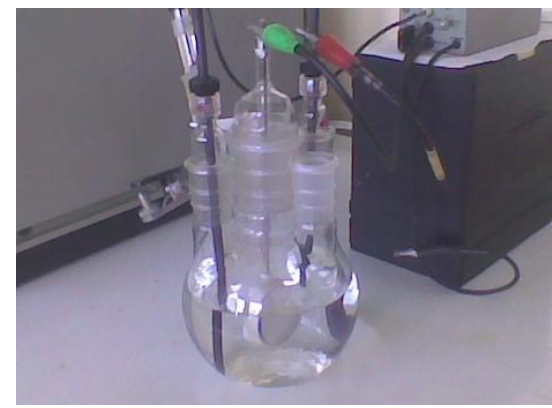

Figure 1. GLASS CELL FOR MEASURING CORROSION RATE 


\section{RESULTS AND DISCUSSIONS}

The carbon steel used as pipes at RGS GAS has chemical composition as shown in Table 1. The hardness of carbon steel is adjusted by the carbon content, but the corrosion behavior is mainly triggered by the environment.

TABLE 1

CHEMICAL COMPOSITION OF SAMPLE

\begin{tabular}{|c|c|}
\hline & $\%$ \\
\hline $\mathrm{C}$ & 0.2 \\
\hline $\mathrm{Mn}$ & 0.4 \\
\hline $\mathrm{Si}$ & 0.1 \\
\hline $\mathrm{P}$ & 0.03 \\
\hline $\mathrm{S}$ & 0.03 \\
\hline
\end{tabular}

The effect of inhibitor at variant concentration at room temperature is shown in Fig.2. The experimental deviation is not more than $20 \%$ at zero inhibitor concentration. From the spread data taken, it shows clearly that the corrosion rate decrease abruptly and nearly approaches half of initial value at the concentration of inhibitor of $75 \mathrm{ppm}$. Then, it continues flat as a constant value.

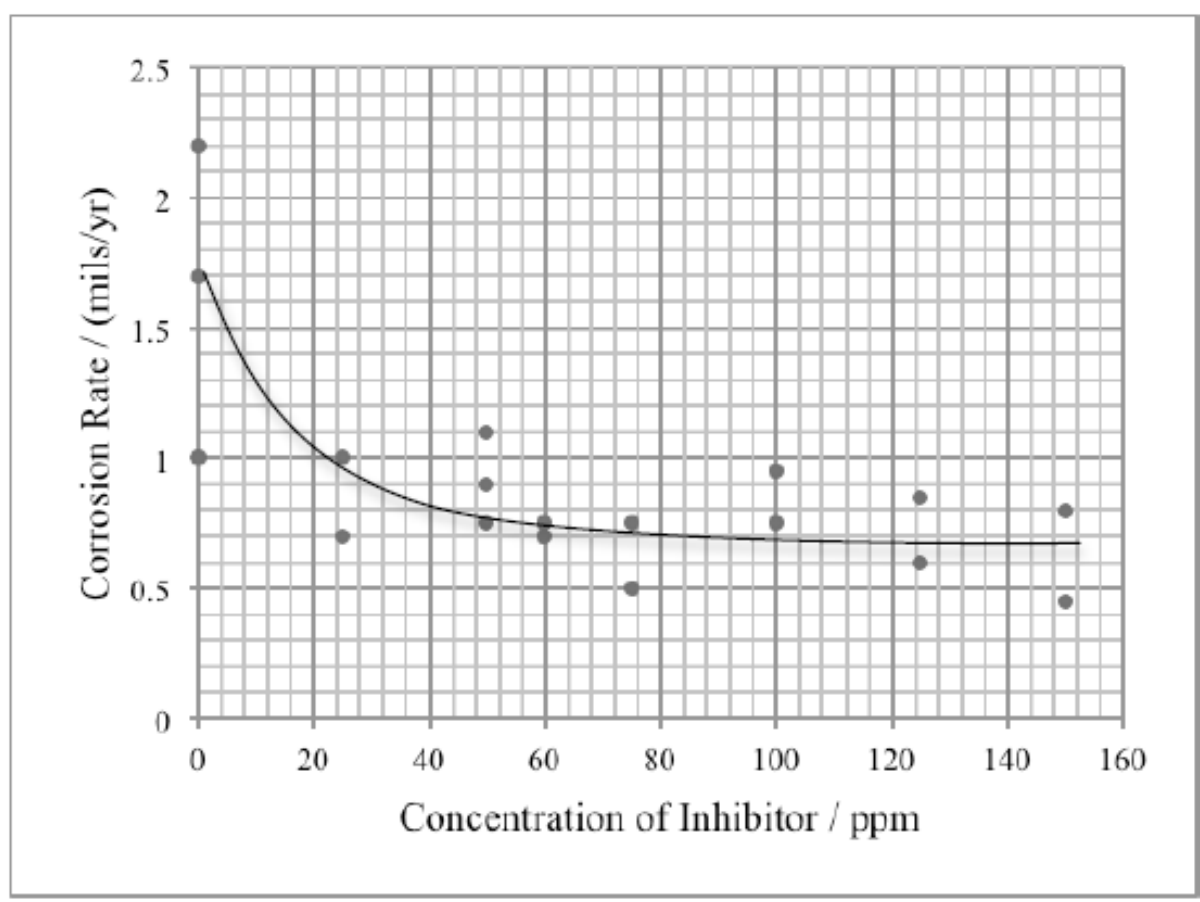

FIGURE 2. THE CORROSION RATE DEPENDENCE ON CONCENTRATION OF INHIBITOR AT ROOM TEMPERATURE FOR CARBON STEEL MATERIAL.

Corrosion mechanism process is based on electrochemical that involve electrons movement as results of redox. [7]

Anodic reaction:

Metal corrosion

Ferrous Ion Oxidation

Oxygen evolution

$$
\begin{array}{lll}
: \mathrm{M} & \rightarrow \mathrm{M}^{\mathrm{n}+}+\mathrm{ne}^{-} \\
: \mathrm{Fe}^{2+} & \rightarrow \mathrm{Fe}^{3+}+\mathrm{e}^{-} \\
: 2 \mathrm{H}_{2} \mathrm{O} & \rightarrow \mathrm{O}_{2}+4 \mathrm{H}^{+} \quad+4 \mathrm{e}^{-}
\end{array}
$$

Cathodic reaction:

$\begin{array}{llll}\text { Hydrogen evolution } & : 2 \mathrm{H}^{+} & +2 \mathrm{e}^{-} & \rightarrow \mathrm{H}_{2} \\ \text { Oxygen reduction (acid) } & : \mathrm{O}_{2} & +4 \mathrm{H}^{+}+4 \mathrm{e}^{-} & \rightarrow 2 \mathrm{H}_{2} \mathrm{O} \\ \text { Oxygen reduction (Neutral/basic) } & : \mathrm{O}_{2} & +2 \mathrm{H}_{2} \mathrm{O}+4 \mathrm{e}^{-} & \rightarrow 4 \mathrm{OH} \\ \text { Metal Ion reduction } & : \mathrm{M}^{3+} & +\mathrm{e}^{-} & \rightarrow \mathrm{M}^{2+} \\ \text { Metal deposition } & : \mathrm{M}^{+} & +\mathrm{e}^{-} & \rightarrow \mathrm{M}\end{array}$


Base on the above reactions, dissolved oxygen $\left(\mathrm{O}_{2}\right)$ is a strong oxidator that induce the corrosion process at cathode and well understood. Therefore, how far the inhibitor effect to dissolved oxygen is has to be understood well. The experimental result for inhibitor effect towards dissolved oxygen concentration change is shown in Fig. 3. The concentration of dissolved oxygen decrease with the increase of inhibitor. The dissolved oxygen concentration at the highest inhibitor concentration become one fifth of the none inhibitor. It shows clearly that the present of inhibitor suppress the dissolved oxygen concentration in the solutions, and may suppress a lot the both cathodic and anodic rate reactions. Finally, it may look that corrosion rate decrease (Fig.3.). Since the limited data gotten at one poin of concentration, the equilibrium effectiveness on inhibitor concentration on suppressing the dissolved oxygen is not appearing. It can be considered that the trend data should be consistent with that of corrosion rate (Fig.3).

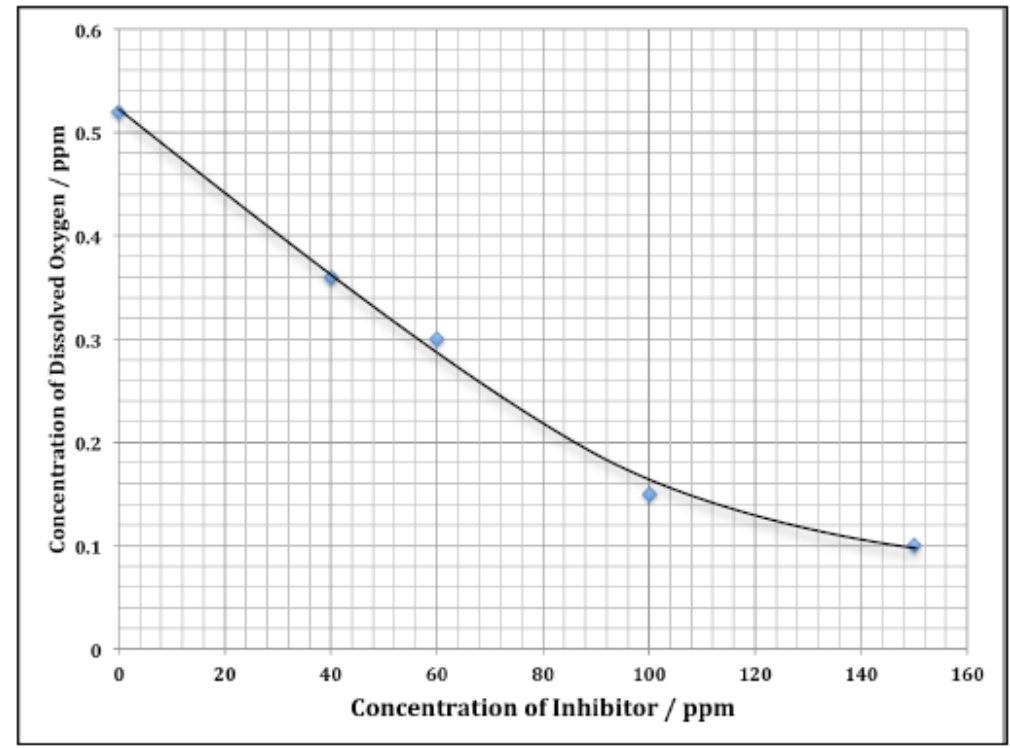

FIGURE 3. THE EFFECT OF INHIBITOR ON SUPPRESSING THE DISSOLVED OXYGEN IN WATER AT ROOM TEMPERATURE.

The inhibition effeiciency is calculated by using the below equation [18];

$$
\text { Inhibitor Efficiency } \left.(\%)=100 \times\left\{\left(\mathrm{CR}_{0}-\mathrm{CR}_{\mathrm{t}}\right) / \mathrm{CR}_{0}\right)\right\}
$$

where :

$\mathrm{CR}_{0}$ is the corrosion rate at zero inhibitor

$\mathrm{CR}_{\mathrm{t}}$ is the corrosion rate at certain concentration of inhibitor

Based on Fig 2, the relation between inhibitor concentration vs inhibition efficiency can be shown in Fig. 4.

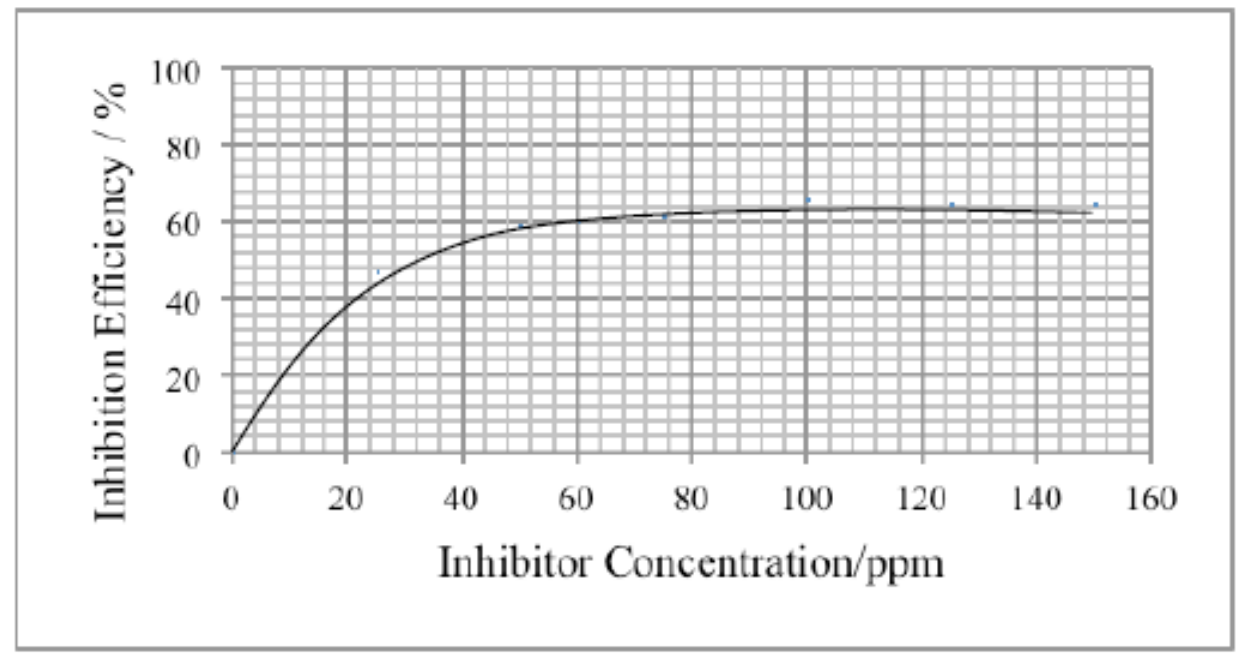

FIGURE 4. INHIBITION EFFICIENCY VS INHIBITION CONCENTRATION AT ROOM TEMPERATURE. 
The inhibition efficiency increase abruptly at higher concentration of inhibitor up to 75ppm. Then it seems to be at constant value at approx 66\%. It can be noted that there is optimal inhibition efficiency. The higher concentration used for inhibitor may not give any further higher inhibition efficiency.

In the real condition, both inhibitor and biocides are added at the same time, so the complex reaction should be occurred. Therefore, for the preliminary study, the effect of biocides on corrosion rate should be investigated separately and was implemented in this experiment. The active compound is orthoprosphate. There are two kind of biocide chemicals, ie. oxy and non oxy. Both are effective for a certain microbe that live needs oxygen and no oxygen, respectively. From the experimental result, it shows that non oxy biocide does not give any effect toward corrosion rate. However, oxy biocide may appear its contribution. It can be understood that, oxy biocide is dedicated to suppress the growing of microbe who need oxygen for their life. The experimental result of the effect of oxy biocide to corrosion rate is shown in Fig.5. The corrosion rate is suppressed abruptly by adding oxy biocide concentration up to $20 \mathrm{ppm}$. Then, no further decrease. Non oxy biocide does not give any effect toward corrosion rate of carbon steel.

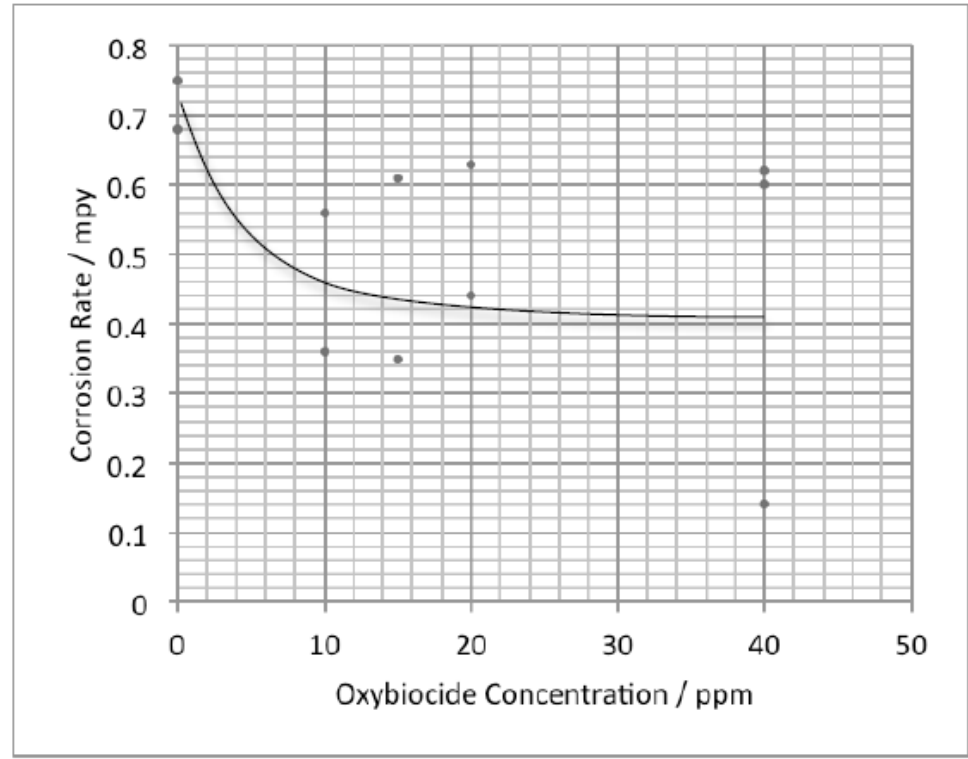

\section{FIGURE 5. THE CORROSION RATE DEPENDENCE ON CONCENTRATION OF OXY BIOCIDE AGENT FOR CARBON STEEL MATERIAL AT ROOM TEMPERATURE}

The experimental result of oxy and non oxy biocide effect to dissolved oxygen concentration is shown in Fig.6. Both oxy and non oxy biocide suppresses the dissolved oxygen concentration. Non oxy biocide gives a slight effect toward corrosion rate, therefore appear no effect toward corrosion rate. However, non oxy biocide suppresses the dissolved oxygen a lot. The concentration of dissolved oxygen decrease from originally become approx. one sixth at $30 \mathrm{ppm}$ of oxy biocide.

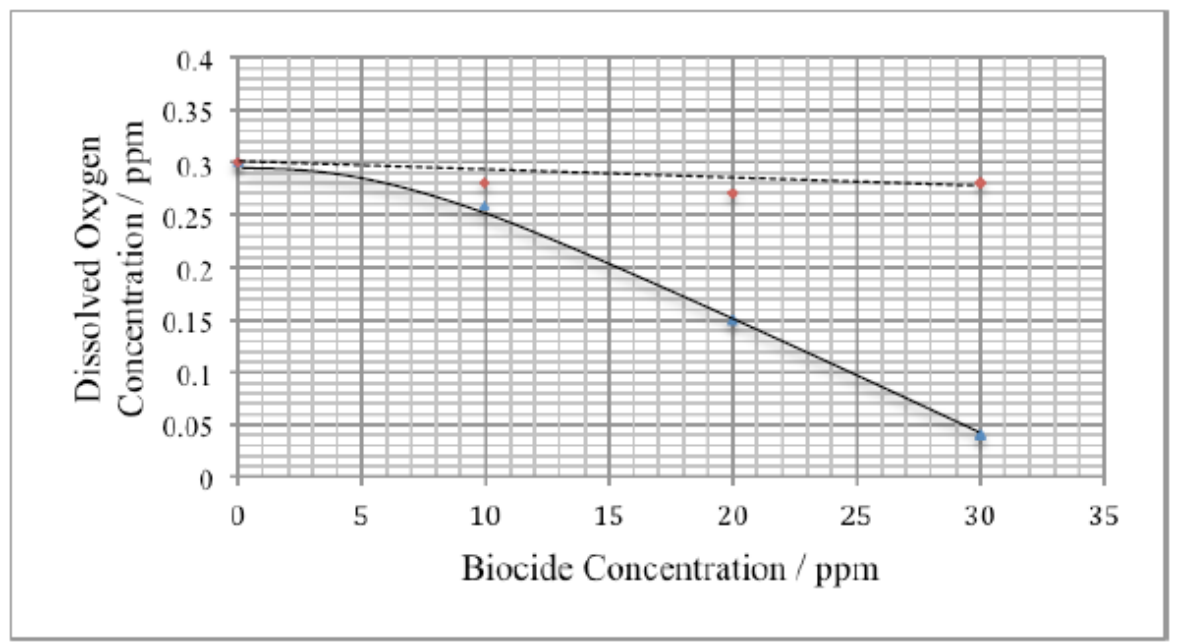

FIGURE 6. THE DISSOLVED OXYGEN DEPENDENCE ON CONCENTRATION OF NON OXY BIOCIDE (---) AND OXY BIOCIDE AGENT (-) AT ROOM TEMPERATURE 
Base on the above experimental results above, the addition of oxy biocide should take into consideration toward the inhibition effect of the inhibitor added into the secondary cooling water of RSG GAS. The further work related with this basic mechanism should be clarified in the future work.

\section{CONCLUSION}

The inhibitor added into the secondary cooling water of RGS GAS is effective to suppress the corrosion rate. The optimum inhibition efficiency is approx. 66\%. The addition of biocide at the same time may give significant effect on inhibition efficiency and need to be clarified in the future work.

\section{ACKNOWLEDGEMENTS}

This experiment is supported by DIPA PTKRN BATAN. Highly appreciate to the colleagues from Center of PTKRN BATAN, PRSG BATAN and PSTBM BATAN for supporting this experiment as well.

\section{REFERENCES}

[1]. Geni Rina Sunaryo, Febrianto, Dyah Erliana dan Budi Utomo, "Analisis kandungan mikroba di Pendingin Sekunder RSG-GAS 30MW”, Prosiding Pertemuan Ilmiah Penelitian Dasar Ilmu Pengetahuan dan Teknologi Nuklir, Yogyakarta, 19 Juli 2011, p. 223229.

[2]. Geni Rina Sunaryo, Aplikasi Program Corrosion Surveillance untuk kolam penyimpan reaktor RSG-GAS, TKPFN-seminar, Surabaya 2010.

[3]. Geni Rina Sunaryo, Sriyono, Diyah Erliana, "Water Chemistry Surveillance for Multi Purpose Reactor 30 MW GA Siwabessy, Indonesia". International Conference on Research Reactors: Safe Management and Effective Utilization Proceeding, Sydney, Australia, 5-9 November 2007.

[4]. Engr Dr A.C Uzorh, "Corrosion Properties of Plain Carbon Steels", The International Journal Of Engineering And Science (IJES), Vol 2, Issue 11, Pages 18-24, 2013. ISSN (e): 2319 - 1813 ISSN (p): $2319-1805$

[5]. Osarolube, E., Owate, I. O. and Oforka, N. C "Corrosion behaviour of mild and high carbon steels in various acidic media", Scientific Research and Essay Vol.3 (6), pp. 224-228, June 2008 Available online at http://www.academicjournals.org/SRE ISSN 1992-2248 () 2008 Academic Journals

[6]. C. Cuevas Arteaga, J. Porcayo Calderón, C. F. Campos Sedano, J. A. Rodríguez, "Comparison of Corrosion Resistance of Carbon Steel and Some Stainless Steels Exposed to LiBr-H2O Solution at low Temperatures”, Int. J. Electrochem. Sci., 7 (2012) 445 - 470.

[7]. EPRI Carbon Steel Handbook, Final Report, March 2007.

[8]. IAEA, TRS 418, "Corrosion of Research Reactor Aluminum Clad Spent Fuel in Water”, 2010

[9]. Kim, Y.S., Hofman, G.L., Robinson, A.B., Snelgrove, J.L., Hanan, N., "Oxidation of aluminum alloy cladding for research and test reactor fuel”, Nuclear Material. 378, page 220-228, 2012

[10]. VS Raja, Bharat S. Padekar., "Role of chlorides on pitting and hydrogen embrittlement of Mg-Mn wrought alloy", Corrosion Science, Vol. 75, October 2013, pp 176-183

[11]. Bhandari Jyoti, Faisal Khan, et.al., "Modelling of pitting corrosion in marine offshore steel structures-A technical review", Journal of Loss Prevention in the Process Industries 37, 2015, pp 39-62.

[12]. Nugraha Luhur, Subiharto, Suhadi, Irwan, "Post Irradiation Material Control Implementation in RSG GA Siwabessy", Nuclear Reactor Management Bulletin, Vol. XI, No.1, April 2014 (in Indonesia)

[13]. Keith A.Lichti et.al., "Galvanic corrosion study of carbon steel to arsenic and antimoby couples", Geo-thermics 58, 2015, pp 15-21

[14]. Biljana S. Maluckov, "Corrosion of Steels Induced by Microorganisms”, Metall. Mater. Eng. Vol 18 (3) 2012 p. $223-231$.

[15]. Nardy Kip and Johannes A van Veen, "The dual role of microbes in corrosion", The ISME Journal (2015) 9, 542-551; doi:10.1038/ismej.2014.169; published online 26 September 2014

[16]. Najoua Labjar, , Mounim Lebrini, , Fouad Bentiss, , Nour-Eddine Chihib, , Souad El Hajjaji, Charafeddine Jama , Corrosion inhibition of carbon steel and antibacterial properties of aminotris (methylenephosphonic) acid, Materials Chemistry and Physics, Volume 119, Issues 1-2, 15 January 2010, Pages 330-336.

[17]. S. Malarvizhi and Shyamala R. Krishnamurthy, "Microbiologically Influenced Corrosion of Carbon Steel Exposed to Biodiesel", International Journal of Corrosion, Volume 2016 (2016), Article ID 4308487, 4 pages, http://dx.doi.org/10.1155/2016/4308487

[18]. T. Sethi, A. Chaturvedi, R.K. Upadhyay and S.P. Mathur, "Corrosion Inhibitory Effects of some Schiff's Bases on Mild Steel in Acid Media”, J. Chil. Chem. Soc. v.52 n.3 Concepción sep. 2007, http: //dx.doi.org/10.4067/S0717-97072007000300003. 